\title{
ENCEFALITE EQÜINA A VÍRUS: ESTUDO DE OCORRÊNCIA NA REGIÃO DA GRANDE CURITIBA, PARANÁ, BRASIL
}

\section{L.R. ALBERTON ${ }^{1}$; R.T.B. RICHARTZ ${ }^{2}$; A.P.P.A. FARACO ${ }^{3}$}

${ }^{1}$ Médico Veterinário Clínico de Grandes Animais - Zooplan Assistência Médica Veterinária Ltda. Aluno do Curso de PosGraduação em Ciências Veterinárias - Universidade Federal do Paraná. ${ }^{2}$ Medico Veterinário Departamento de Virologia - Centro de Diagnóstico Marcos Enrietti. ${ }^{3}$ Acadêmica do Curso de Medicina Veterinária da Pontifícia Universidade Católica do Paraná.

Conforme a Secretaria Estadual da Agricultura não existiam registros de surtos de encefalite eqüina a vírus na Região Metropolitana de Curitiba confirmados através de exames laboratoriais. De acordo com levantamento sorológico feito pelo Centro de Diagnóstico Marcos Enrietti*, 40\% das amostras de soro de animais não vacinados de todas as regiões do Estado do Paraná mostraram-se reagentes para a encefalite viral (cepas leste e oeste), confirmando a circulação do vírus nos animais do Estado. Através de fontes do mesmo laboratório foi verificado que no ano de 1997 foram confirmados casos da doença apenas na região norte do Estado (Paranavaí, Querência do Norte, Colorado e Cafeara), atestados pelo método de soroneutralização. Até então, não se havia conseguido o isolamento viral a partir de amostras colhidas de animais doentes no estado do Paraná. A criação onde ocorreu o surto está situada em Almirante Tamandaré a aproximadamente 15 quilômetros do centro da cidade de Curitiba. Os casos ocorreram em 14.03.98, sendo os quatro animais fêmeas adultas. Três delas nascidas na propriedade nunca haviam sido vacinadas contra encefalite viral e a outra égua estava há cinco anos neste local só tendo sido vacinada pelo antigo proprietário. Ao exame clínico estes animais apresentavam os seguintes sinais: deficiência proprioceptiva: quando tentavam se levantar e manter-se em estação tinham muita dificuldade, e quando tentavam deambular apresentavam marcha rija, e incoordenada principalmente dos membros pélvicos; - hiperexcitabilidade: os animais se chocavam contra obstáculos quando sofriam estimulação táctil ou sonora; - movimentos incoordenados de cabeça e pescoço, hábito de mordiscar as paletas e às vezes movimentos lateralizados e incoordenados dos lábios, principalmente os inferiores; - os animais apresentavam reflexo de ameaça e o apetite estava presente, alguns até pastavam quando em decúbito esternal. Os animais doentes foram separados do resto do rebanho, e tratados com antimicrobianos à base de sulfa e trimetoprim, antiinflamatórios não esteróides, dimetilsulfóxido, e terapia de suporte (solução glicosada, e vitaminas) por via endovenosa.

No dia 16.03.98, dois dos quatro animais foram submetidos à eutanásia pois não conseguiam mais se alimentar, permaneciam em decúbito lateral e se debatiam com violência se autotraumatizando. Desses animais foi colhido sangue integral com e sem anticoagulante, amostra de líquido cefalorraquidiano, rins e fígado.Os outros dois animais apresentavam sinais de melhora com a medicação. Na necrópsia, em dois dos animais submetidos a eutanásia foram constatadas alterações indicando pneumonia, provavelmente devido ao decúbito prolongado, congestão e aderência de cápsula renal e hiperemia nas meninges. Histologicamente, o encéfalo exibia uma menigoencefalite não supurativa, com necrose de neurônios, satelitose, neuronofagia, espongiose, hemorragia e infiltração inflamatória principalmente por mononucleares, neutrofilia nos vasos, necrose das células de Purkinje e depósitos síderocalcáreos nos vasos do pedúnculo cerebral. O fígado apresentava transformação gordurosa, e os rins necrose do epitélio de grupos de túbulos na cortical. No exame do líquor verificou-se aumento na quantidade de glicose e de hemácias. $\quad$ Os métodos utilizados para sorologia e isolamento viral foram os seguintes: - Técnicas segundo Shope \& Sather para a sorologia e soroneutralização respectivamente; - Detecção de antígeno em cortes a frio do material encefálico por imunofluorescência indireta (IFI), utilizando-se anticorpos monoclonais frente aos vírus da encefalite eqüina a vírus cepa leste (EEE) e encefalite eqüina a vírus cepa oeste (WEE); - O isolamento viral foi feito através da inoculação em camundongos de 1 a 3 dias de idade com suspensão cerebral a $20 \%$ em tampão fosfatado com $0,5 \%$ de albumina bovina. Inoculação em cultura de células VERO de suspensão cerebral. Os animais em questão reagiram positivamente aos testes acima mencionados para encefalite eqüina a vírus cepa leste. Conclusão: Em virtude dos resultados laboratoriais não restam dúvidas de que a encefalite eqüina a vírus ocorre nesta região; principalmente nas épocas de chuvas com temperaturas mais elevadas, favorecendo a procriação dos insetos transmissores. Portanto é de grande importância a vacinação dos eqüinos desta região.

* O Centro de Diagnóstico Marcos Enrietti é vinculado a Secretaria Estadual da Agricultura - Departamento de Fiscalização. 